\title{
PERAN EEP PADA PERILAKU ENTREPRENEURIAL DAN KEPUASAN KINERJA PERAJIN BATIK SURAKARTA, KARANGANYAR DAN SRAGEN
}

\author{
Asri Laksmi Riani \\ Fakultas Ekonomi Universitas Sebelas Maret \\ e-mail: asrilaksmiriani@yahoo.com \\ Hunik Sri Runing Sawitri \\ Fakultas Ekonomi Universitas Sebelas Maret \\ e-mail: hunik_sri@yahoo.co.id \\ Rahmawati \\ Fakultas Ekonomi Universitas Sebelas Maret \\ e-mail: rahmaw2005@yahoo.com
}

\begin{abstract}
The aim of this study is to develop a model of entrepreneurship education linkages (EEP) on attitudes, subjective norms, perceived behavioral control which influences the intention to define entrepreneurship and entrepreneurial behavior. The research was conducted in three areas; Surakarta, Sragen and Karanganyar. Respondents in this study are artisans of batik with SEM analysis. The analysis showed that: 1). Entrepreneurship education program (EEP) gave the positive effect on entrepreneurial attitudes, subjective norms, perceived behavioral control 2). Entrepreneurial attitudes, subjective norms, and perceived behavioral control gave positive influences on the intention to entrepreneurship, 3). Intention to entrepreneurship has no effects on entrepreneurial behavior, 4). Satisfaction has a positive effect on innovation performance satisfaction, 5). Target entrepreneurial behavior has no effect on the satisfaction of performance.
\end{abstract}

Keywords: EEP, intention to entrepreneurship, entrepreneurial behavior, satisfaction innovation, satisfaction performance.

\begin{abstract}
Abstrak
Penelitian ini bertujuan untuk mengembangkan model keterkaitan program pendidikan kewirausahaan (EEP) pada sikap, norma subyektif, persepsi kontrol perilaku dan selanjutnya mempengaruhi niat untuk berwirausaha dan menentukan target perilaku berwirausaha. Penelitian ini juga menguji dan mengembangkan model program pendidikan kewirausahaan (EEP) pada kepuasan inovasi serta pada kepuasan kinerja. Penelitian ini dilakukan di wilayah: Kota Surakarta, Kabupaten Sragen, dan Kabupaten Karanganyar. Responden dalam penelitian ini adalah perajin batik, dengan alat analisis SEM (Structural Equation Modeling). Hasil analisis menunjukkan bahwa: 1). Program pendidikan kewirausahaan (EEP) berpengaruh positif pada sikap kewirausahaan, norma subyektif, persepsi kontrol perilaku serta kepuasan inovasi 2). Sikap kewirausahaan, norma subyektif dan persepsi kontrol perilaku berpengaruh positif pada niat untuk berwirausaha, 3). Niat untuk berwirausaha tidak berpengaruh pada target perilaku berwirausaha, 4). Kepuasan inovasi berpengaruh positif pada kepuasan kinerja, 5). Target perilaku berwirausaha tidak berpengaruh pada kepuasan kinerja.
\end{abstract}

Kata kunci: EEP, niat, kepuasan inovasi, perilaku berwirausaha, kepuasan kinerja. 


\section{PENDAHULUAN}

Saat ini kompetisi pasar semakin meningkat yang menuntut semua pihak untuk dapat menghasilkan produk atau jasa yang terbaik dalam memenangkan persaingan. Era globalisasi memaksa organisasi/perusahaan memperhatikan dan meningkatkan kualitas produk atau layanan yang diberikan. Selain peningkatan kualitas diperlukan pula inovasi dalam proses pengembangan suatu produk atau jasa.

Dalam menciptakan produk berkualitas dan bersifat inovatif merupakan salah satu bentuk apresiasi perbaikan produk berkelanjutan yang merupakan proses pengembangan produk difokuskan pada konsumen. Kualitas produk dan pengelolaannya dikaitkan dengan perbaikan berkelanjutan dilakukan oleh banyak perusahaan agar dapat mendorong peningkatan pasar dan memenangkan persaingan.

Kewirausahaan telah lama menjadi perhatian yang penting dalam mengembangkan pertumbuhan ekonomi di suatu negara. Selain dapat membantu menyediakan kesempatan kerja, berbagai kebutuhan konsumen, serta menumbuhkan kesejahteraan dan tingkat kompetisi suatu negara, kewirausahaan juga menjadi perhatian penting dalam menghadapi tantangan kompetisi ekonomi global dalam hal kreativitas dan inovasi.

Upaya untuk memecahkan permasalahan tingginya tingkat pengangguran, kemiskinan dan rendahnya daya saing negara dapat dilakukan dengan meningkatkan pendidikan maupun budaya berwirausaha. Peningkatan pendidikan diharapkan dapat memberikan pengetahuan dan kemampuan masyarakat untuk dapat menguasai pengetahuan dan teknologi, sehingga mereka mampu bersaing dalam dunia kerja secara profesional. Sedangkan upaya untuk meningkatkan budaya berwirausaha diharapkan dapat mendorong terciptanya wirausaha baru yang tidak saja mampu menciptakan usaha, tetapi sekaligus dapat menyerap tenaga kerja terdidik sehingga produk yang dihasilkan mampu bersaing di pasar (Cooper et al., 1994; Kennedy and Drennan, 2001).

Program pendidikan kewirausahaan (Education Enterpreneurship Programmel EEP) ditujukan untuk mempengaruhi masa depan perilaku kewirausahaan individu dan meningkatkan kesuksesan bisnis. Program ter- sebut bertujuan untuk meningkatkan minat pengusaha/mahasiswa tentang karir kewirausahaan dan untuk meningkatkan kesadaran para pejabat publik tentang pentingnya kewirausahaan sebagai kontributor untuk pembangunan ekonomi (Fayolle et al., 2006).

Untuk menilai dampak dari program EEP mengacu pada teori planned behavior. Teori ini digunakan dalam perbedaan konteks, tempat, dan populasi untuk menilai niat dan perilaku, dan sekarang telah digunakan untuk mengevaluasi program EEP (Fayolle et al., 2006). Secara khusus, Fayolle et al. (2006) menunjukkan bagaimana program EEP mempengaruhi tiga faktor utama dari teori planned behavior. Disajikan dalam perilaku kewirausahaan, teori ini menyebutkan bahwa niat untuk berwirausaha dan keputusan untuk melakukan operasi bisnis tergantung pada sikap kewirausahaan, cara merasakan bagaimana tekanan sosial mempengaruhi perilaku kewirausahaan, dan persepsi mengontrol perilaku (Cruz et al., 2009). Permasalahan penelitian ini adalah akan mengembangkan model keterkaitan program EEP pada sikap, norma subyektif, dan persepsi kontrol perilaku, yang selanjutnya mempengaruhi niat untuk berwirausaha dan menentukan perilaku target berwirausaha. Penelitian ini juga menguji dan mengembangkan model program EEP pada kepuasan inovasi dan pada kepuasan kinerja

\section{KAJIAN PUSTAKA DAN HIPOTESIS}

\section{Pengaruh Program Pendidikan (EEP) pada Sikap, Norma Subyektif, dan Persepsi Kontrol Perilaku}

Untuk menilai dampak dari program pendidikan kewirausahaan (EEP) mengacu pada teori planned behavior. Teori ini digunakan dalam perbedaan konteks, tempat, dan populasi untuk menilai niat dan perilaku, dan sekarang telah digunakan untuk mengevaluasi program pendidikan kewirausahaan (EEP) (Fayolle et al., 2006). Fayolle et al. (2006) menunjukkan bagaimana program pendidikan kewirausahaan (EEP) mempengaruhi tiga faktor utama dalam teori planned behavior. Teori ini menyebutkan bahwa niat untuk berwirausaha dan keputusan untuk melakukan operasi bisnis tergantung pada sikap kewirausahaan, cara merasakan bagaimana tekanan sosial mempengaruhi peri- 
laku kewirausahaan, dan persepsi kontrol perilaku (Cruz et al., 2009).

Berdasarkan uraian yang telah dijelaskan, maka hipotesis 1 dalam penelitian ini adalah sebagai berikut:

H1a: Program pendidikan kewirausahaan (EEP) berpengaruh positif pada sikap kewirausahaan.

H1b: EEP berpengaruh positif pada norma subyektif

H1c: EEP berpengaruh positif pada persepsi kontrol perilaku.

Pengaruh Sikap, Norma Subyektif, dan Persepsi Kontrol Perilaku pada Niat untuk Berwirausaha

Faktor utama dari teori planned behavior adalah niat individu untuk melakukan perilaku tertentu. Teori planned behavior, menyebutkan bahwa ada tiga faktor sebagai antecedent niat (intention) dan bisa mempengaruhi perilaku masa depan. Tiga faktor tersebut antara lain: sikap, norma subyektif, dan kontrol perilaku (Fayolle et al., 2006).

Hasil penelitian Tkachev and Kot vereid (1999) menunjukkan bahwa variabel norma subyektif berpengaruh pada niat berwirausaha. Banyak hasil penelitian tentang hubungan antara sikap dan niat berwirausaha, secara konsisten menunjukkan hubungan yang konsisten. Misalnya, hasil penelitian Kolvereid (1996); Tkachev and Kolvereid (1999); Schwarz et al. (2009). Penelitian Guido et al.,
(2011) menemukan bahwa sikap, norma subyektif dan persepsi kontrol perilaku sebagai antecedent niat berwirausaha. Penelitian yang telah dilakukan oleh Riani et al. (2011) menunjukkan bahwa niat berwirausaha mahasiswa dipengaruhi oleh norma subyektif, sikap terhadap kewirausahaan, dan dukungan lembaga (UNS). Berdasarkan uraian yang dijelaskan tersebut, maka hipotesis 2 dalam penelitian ini adalah sebagai berikut:

H2a: Sikap berpengaruh positif pada niat untuk berwirausaha

H2b: Norma subyektif berpengaruh positif pada niat untuk berwirausaha

H2c: Persepsi kontrol perilaku berpengaruh positif pada niat untuk berwirausaha.

\section{Pengaruh Niat untuk Berwirausaha pada Target Perilaku Berwirausaha}

Banyak hasil penelitian tentang hubungan sikap dan niat berwirausaha, secara konsisten menunjukkan hubungan yang positif, seperti hasil penelitian Kolvereid (1996); Tkachev and Kolvereid (1999); Schwarz et al. (2009). Hasil penelitian Fayolle et al. (2006) menunjukkan bahwa niat berwirausaha mempunyai pengaruh positif pada target perilaku berwirausaha.

Berdasarkan uraian yang telah dijelaskan, maka hipotesis 3 dalam penelitian ini adalah sebagai berikut:

H3: Niat berwirausaha bepengaruh positif pada perilaku berwirausaha.

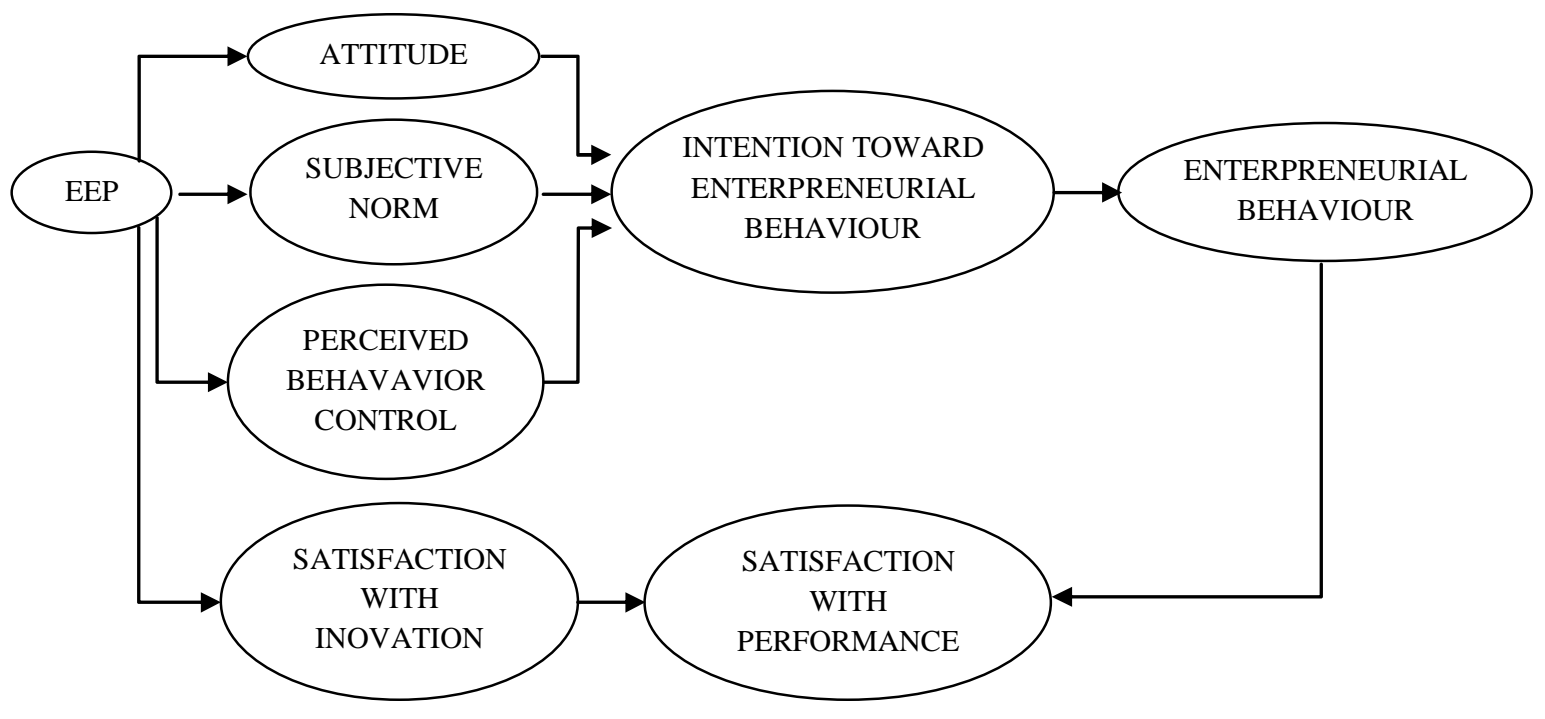

Gambar 1: Model Penelitian 


\section{Pengaruh EEP pada Kepuasan Inovasi}

Penelitian ini menggunakan pendekatan teori planned behavior untuk menganalisis pengaruh program pendidikan kewirausahaan (EEP) pada perilaku kewirausahaan dan kinerja. Perilaku inovatif diukur dengan variabel "kepuasan inovatif". Cruz et al. (2009) mengusulkan model dimana program pendidikan kewirausahaan (EEP) berpengaruh langsung pada kepuasan inovasi. Cruz et al. (2009) menemukan bahwa pengusaha yang menggunakan strategi berbasis inovasi menggerakkan perekonomian dan struktur teknologi yang didasarkan pada inovasi. Hipotesis 4 dalam penelitian ini adalah sebagai berikut:

H4: Program Pendidikan Kewirausahaan (EEP) berpengaruh positif pada kepuasan kinerja

\section{Pengaruh Kepuasan Inovasi pada Kepuasan Kinerja}

Penelitian ini menggunakan pendekatan teori planned behavior untuk menganalisis pengaruh EEP pada perilaku kewirausahaan dan kinerja. Cruz et al. (2009) mengusulkan model dimana EEP berpengaruh langsung pada kepuasan kinerja dan menguji pengaruh inovasi pada kinerja menggunakan variabel "kepuasan kinerja". Disusun hipotesis 5 dalam penelitian ini adalah:

H5: Kepuasan inovasi berpengaruh positif pada kepuasan kinerja

\section{Pengaruh Perilaku Berwirausaha pada Kepuasan Kinerja}

Cruz et al. (2009) mengusulkan model dimana perilaku berwirausaha berpengaruh langsung pada kepuasan kinerja menggunakan variabel "kepuasan kinerja". Berdasarkan uraian yang dijelaskan tersebut, maka hipotesis 6 dalam penelitian ini adalah sebagai berikut:

H6: Perilaku berwirausaha berpengaruh positif pada kepuasan kinerja

\section{METODE PENELITIAN}

Penelitian ini adalah penelitian cross-sectional, dengan menggunakan desain survey sebagai tehnik pengumpulan data.

\section{Populasi, Sampel dan Teknik Sampling}

Populasi dalam penelitian ini adalah perajin batik di wilayah Kota Surakarta, Kabupaten
Sragen, dan Kabupaten Karanganyar. Pengambilan sampel dilakukan dengan menggunakan teknik purposive sampling, yaitu teknik pengambilan sampel dengan menggunakan pertimbangan atau kriteria tertentu. Kriteria sampel yang diambil yaitu perajin batik yang sudah bekerja minimal 1 (satu) tahun.

\section{Pengukuran Variabel}

\section{Program pendidikan kewirausahaan (EEP)}

Program EEP berdasarkan tiga dimensi, yaitu: pendidikan kewirausahaan, pendidikan khusus, dan pendidikan formal (Cruz et al., 2009), dengan menggunakan kerangka pikir pendidikan kewirausahaan (Mwasalwiba, 2010).

\section{Sikap kewirausahaan (attitude)}

Sikap kewirausahaan diukur dengan menggunakan 4 indikator: senang dengan pimpinan yang menjamin pekerjaan; lebih senang menemukan perusahaan baru yang memungkinkan menjadi salah satu manajernya; senang bisa bekerja mandiri; senang dapat membuka usaha sendiri (Schwarz et al., 2009)

\section{Norma subyektif (subjective norm)}

Norma subyektif diukur dengan menggunakan 3 indikator: dukungan keluarga; dukungan teman pergaulan; dukungan rekan kerja (Linan and Chen, 2009).

\section{Persepsi kontrol perilaku (perceived beha-} vioral control)

Persepsi kontrol perilaku diukur dengan menggunakan 6 indikator (Linan, and Chen, 2009).

Niat berwirausaha (intention toward entrepreneurial behavior)

Niat berwirausaha diukur dengan menggunakan 3 indikator, yaitu: niat untuk menyiapkan bisnisnya sendiri; niat menyiapkan bisnis yang lain dalam dua tahun ke depan; niat menyiapkan bisnis yang lain dalam lima tahun ke depan (Schwarz et al 2009).

Kepuasan inovasi (satisfaction with innovation) Kepuasan inovasi diukur dengan menanyakan "tingkat kepuasan terhadap inovasi dalam produk atau jasa (Cruz et al., 2009).

Kepuasan kinerja (satisfaction with performance) 
Kepuasan kinerja diukur dengan "tingkat Return of Equity (ROE)" (Cruz et al 2009).

\section{Uji Instrumen}

\section{Uji validitas}

Uji Validitas dari penelitian ini menggunakan factor analysis dengan bantuan paket perangkat lunak program SPSS for Windows versi 11.5. dengan teknik analisis adalah menggunakan Confirmatory Factor Analysis (CFA).

\section{Uji reliabilitas}

Dalam penelitian ini, uji reliabilitas dilakukan menggunakan metode Cronbach's Alpha. dengan menggunakan bantuan program SPSS for Windows versi 11.5.

\section{Uji hipotesis}

Analisis dalam penelitian ini menggunakan Structural Equation Modeling (SEM) dengan program aplikasi Analysis of Moment Structure (AMOS).

\section{HASIL ANALISIS}

\section{Tanggapan Responden Mengenai Program Pendidikan Kewirausahaan (EEP)}

Deskripsi tanggapan responden sebanyak 206 orang terhadap item pernyataan EEP sebagaimana disajikan pada tabel 1 .

Tabel 1 menunjukkan bahwa program pelatihan yang banyak diikuti responden adalah praktik pembuatan produk kreatif dan produk inovatif/baru dari batik, pembekalan manajerial dan penyusunan perencanaan usaha serta pelatihan outbound kewirausahaan.

\section{Uji Validitas}

Berdasarkan hasil uji validitas dengan jumlah 206 responden, terlihat ada dua item yang tidak valid karena memiliki nilai loading factor < 0,50, yaitu A1 dan A2. Selanjutnya, dilakukan pengujian validitas lagi dengan tidak mengikutsertakan item yang tidak valid. Hasilnya menunjukkan semua item valid.

Tabel 1: Deskripsi Tanggapan Responden pada

Program Pendidikan Kewirausahaan (EEP)

\begin{tabular}{clc}
\hline No & \multicolumn{1}{c}{ Pernyataan } & Frekuensi \\
\hline & Program pembelajaran yang dilakukan: & \\
1 & Pelatihan outbound kewirausahaan & 76 \\
2 & Pembekalan manajerial dan penyusunan perencanaan usaha & 78 \\
3 & Pelatihan pembuatan produk kreatif dari 'batik' & 77 \\
4 & Praktik pembuatan produk kreatif \& produk inovatif/baru dari 'batik' & 97 \\
5 & Lomba karya cipta kreasi batik & 34 \\
6 & Pelatihan motivasi bisnis (BMT) & 64 \\
7 & Pelatihan pelayanan prima & 43 \\
8 & Pelatihan motivasi berprestasi (AMT) & 37 \\
9 & Lainnya & 12 \\
\hline
\end{tabular}

Sumber: Data primer yang diolah, 2012.

Tabel 2. Hasil Goodness-of-Fit Model

\begin{tabular}{lrrl}
\hline \multicolumn{1}{r}{ Goodness-of-fit Indices } & Cut-off Value & \multicolumn{1}{c}{ Hasil } & \multicolumn{1}{c}{ Evaluasi Model } \\
\hline Chi-Square $\left(\chi^{2}\right)$ & Diharapkan kecil & 224,211 & - \\
Significance Probability $(p)$ & $\geq 0,05$ & 0,000 & Belum memenuh \\
CMIN/DF & $\leq 2,0$ & 1,495 & Baik \\
GFI & $\geq 0,9$ & 0,901 & Baik \\
AGFI & $\geq 0,9$ & 0,862 & Belum memenuhi \\
TLI & $\geq 0,9$ & 0,966 & Baik \\
CFI & $\geq 0,9$ & 0,973 & Baik \\
RMSEA & $\leq 0,08$ & 0,049 & Baik \\
& & & \\
\hline
\end{tabular}

Sumber: Data primer yang diolah, 2012 


\section{Uji Reliabilitas}

Nilai batas yang digunakan untuk menilai adalah sebuah tingkat reliabilitas yang dapat diterima adalah 0,7. Dengan demikian maka berdasarkan hasil perhitungan, kelima variabel dinyatakan reliabel.

\section{Uji Hipotesis}

Teknik pengujian digunakan untuk menguji hipotesis dan menghasilkan suatu model yang baik. Untuk menguji digunakan Structural Equation Modeling (SEM) dengan bantuan program AMOS 6.

\section{Analisis Kesesuaian Model (Goodness-of-Fit)}

Tabel 2 menjelaskan hasil goodness of fit dari model penelitian yang dilakukan. Dalam pengujian ini nilai Chi-Square dengan $\mathrm{p}<0,05$ dan hanya nilai CMIN/DF yang memenuhi, maka peneliti mempertimbangkan untuk melakukan modifikasi eror untuk membentuk model alternatif yang mempunyai goodness of fit yang lebih baik. Modification indices yang dapat diketahui dari output Amos akan menunjukkan hubungan yang perlu diestimasi yang sebelumnya tidak ada dalam model untuk mendapatkan model penelitian yang lebih baik. Déstimasi hubungan korelasi antar error term yang memiliki nilai modification indices lebih besar atau sama dengan 4.0 (Ferdinand, 2006). Tabel 2 merupakan hasil goodness of fit model yang telah dimodifikasi.

Tabel 2 menunjukkan nilai chi-square menghasilkan tingkat signifikansi lebih kecil dari 0,05 dengan nilai chi-square sebesar
224,211 yang berarti bahwa chi-square belum memenuhi. Nilai CMIN/DF, GFI, TLI, CFI dan RMSEA dalam model penelitian ini menunjukkan tingkat kesesuaian yang baik. Sedangkan nilai AGFI meningkat tetapi juga belum memenuhi. Secara keseluruhan pengukuran goodness of fit mengindikasikan bahwa model yang diajukan dalam penelitian dapat diterima.

\section{Analisis Koefisisen Jalur}

Analisis ini dilihat dari signifikansi besaran regression weight model yang dapat dilihat pada Tabel 3. Hasil pengujian menunjukkan bahwa dari sepuluh jalur yang dianalisis, terdapat dua jalur yang memiliki pengaruh tidak signifikan, yaitu pengaruh niat berwirausaha pada perilaku dan pengaruh perilaku pada kepuasan kinerja.

\section{PEMBAHASAN}

\section{Program EEP Berpengaruh Positif pada Sikap Kewirausahaan}

Berdasarkan hasil perhitungan pada Tabel 3 didapatkan hasil nilai C.R EEP pada sikap kewirausahaan adalah sebesar 4,562 dengan tingkat signifikansi $\mathrm{p}<0,05$, maka hipotesis $1 a$ didukung. Dapat disimpulkan bahwa dalam penelitian ini EEP berpengaruh positif pada sikap kewirausahaan. Semakin banyak program pendidikan kewirausahaan (EEP) yang diikuti perajin batik maka sikap kewirausahaan perajin batik tersebut juga akan semakin tinggi. Hasil penelitian ini mendukung penelitian yang dilakukan oleh Fayolle et al., (2006).

Tabel 3: Regression Weights

\begin{tabular}{llrrrr}
\hline & & Estimat & S.E. & C.R. & \multicolumn{2}{l}{$\mathrm{P}$} \\
\hline Attitude & $\mathrm{e}$ & .527 & .116 & 4.562 & .000 \\
Norma Subyektif & $\leftarrow$ eep & .175 & .058 & 2.994 & .003 \\
Perceived Behavior Control & $\leftarrow$ eep & .454 & .158 & 2.878 & .004 \\
Niat Berwirausaha & $\leftarrow$ Attitude & .325 & .075 & 4.335 & .000 \\
Niat Berwirausaha & $\leftarrow$ Norma Subyektif & .612 & .161 & 3.790 & .000 \\
Niat Berwirausaha & $\leftarrow$ Perceived Behavior Control & .527 & .065 & 8.116 & .000 \\
tp & $\leftarrow$ Niat Berwirausaha & -.222 & .114 & -1.940 & .052 \\
ki & $\leftarrow$ eep & .561 & .162 & 3.456 & .000 \\
Kepuasan Kinerja & $\leftarrow$ ki & .431 & .051 & 8.494 & .000 \\
Kepuasan Kinerja & $\leftarrow$ tp & .040 & .033 & 1.208 & .227 \\
\hline Suna
\end{tabular}

Sumber: Data primer yang diolah, 2012 


\section{Program EEP Berpengaruh Positif pada Norma Subyektif}

Berdasarkan hasil perhitungan pada Tabel 3 didapatkan hasil nilai C.R EEP pada norma subyektif adalah sebesar 2,994 dengan tingkat signifikansi $\mathrm{p}<0,05$, maka hipotesis $1 b$ didukung. Disimpulkan bahwa EEP berpengaruh positif pada norma subyektif. Semakin banyak program EEP yang diikuti perajin batik maka norma subyektif perajin batik tersebut juga akan semakin tinggi. Hasil penelitian ini mendukung penelitian yang dilakukan oleh Fayolle et al., (2006).

\section{Program EEP Berpengaruh Positif pada Persepsi Kontrol Perilaku}

Berdasarkan hasil perhitungan pada Tabel 3 didapatkan hasil nilai C.R EEP pada persepsi kontrol perilaku adalah sebesar 2,878 dengan tingkat signifikansi $\mathrm{p}<0,05$, maka hipotesis $1 c$ didukung. Disimpulkan bahwa EEP berpengaruh positif pada persepsi kontrol perilaku. Semakin banyak program EEP yang diikuti perajin batik maka persepsi kontrol perilaku perajin batik tersebut juga akan semakin baik. Hasil penelitian ini mendukung penelitian yang dilakukan oleh Fayolle et al., (2006).

\section{Sikap Berpengaruh Positif Pada Niat untuk Berwirausaha}

Berdasarkan hasil perhitungan pada Tabel 3 didapatkan hasil nilai C.R sikap pada niat untuk berwirausaha adalah sebesar 4,335 dengan tingkat signifikansi $\mathrm{p}<0,05$, maka hipotesis $2 a$ didukung. Disimpulkan bahwa sikap berpengaruh positif pada niat untuk berwirausaha. Semakin tinggi sikap kewirausahaan yang dimiliki perajin batik maka niat untuk berwirausaha perajin batik tersebut juga akan semakin tinggi. Hasil penelitian ini mendukung penelitian yang dilakukan oleh Guido et al., (2011) dan Riani et al. (2011).

\section{Norma Subyektif Berpengaruh Positif Pada Niat untuk Berwirausaha}

Berdasarkan hasil perhitungan pada Tabel 3 didapatkan hasil nilai C.R norma subyektif pada niat untuk berwirausaha adalah sebesar 3,790 dengan tingkat signifikansi $\mathrm{p}<0,05$, maka hipotesis $2 b$ didukung. Disimpulkan bahwa norma subyektif berpengaruh positif pada niat untuk berwirausaha. Semakin tinggi norma subyektif yang dimiliki perajin batik maka niat untuk berwirausaha perajin batik tersebut juga akan semakin tinggi. Hasil penelitian ini mendukung penelitian yang dilakukan oleh Guido et al., (2011) dan Riani et al., (2011).

\section{Persepsi Kontrol Perilaku Berpengaruh Positif Pada Niat untuk Berwirausaha}

Berdasarkan hasil perhitungan pada Tabel 3 didapatkan hasil nilai C.R persepsi kontrol perilaku pada niat untuk berwirausaha adalah sebesar 8,116 dengan tingkat signifikansi $\mathrm{p}<0,05$, maka hipotesis $2 c$ didukung. Disimpulkan bahwa persepsi kontrol perilaku berpengaruh positif pada niat untuk berwirausaha. Semakin tinggi persepsi kontrol perilaku yang dimiliki perajin batik maka niat untuk berwirausaha perajin batik tersebut juga akan semakin tinggi. Hasil penelitian ini mendukung penelitian yang dilakukan oleh Guido et al., (2011) dan Riani et al., (2011).

\section{Niat Berwirausaha Bepengaruh Positif pada Perilaku Berwirausaha}

Berdasarkan hasil perhitungan pada Tabel 3 didapatkan hasil nilai C.R niat berwirausaha pada perilaku berwirausaha adalah sebesar 1,940 dengan tingkat signifikansi $\mathrm{p}>0,05$, maka hipotesis 3 tidak didukung. Disimpulkan bahwa niat berwirausaha tidak berpengaruh pada perilaku berwirausaha. Hasil penelitian ini tidak mendukung penelitian yang dilakukan oleh Fayolleet al. (2006).

\section{Program EEP Berpengaruh Positif pada Kepuasan Inovasi}

Berdasarkan hasil perhitungan pada Tabel 3 didapatkan hasil nilai C.R EEP pada kepuasan inovasi adalah sebesar 3,456 dengan tingkat signifikansi $\mathrm{p}<0,05$, maka hipotesis 4 didukung. Disimpulkan bahwa EEP berpengaruh positif pada kepuasan inovasi. Semakin banyak program EEP yang diikuti perajin batik maka kepuasan inovasi perajin batik tersebut juga akan semakin tinggi. Hasil penelitian ini mendukung penelitian yang dilakukan oleh Cruz et al. (2009).

\section{Kepuasan Inovasi Berpengaruh Positif pada Kepuasan Kinerja}

Berdasarkan hasil perhitungan pada Tabel 3 didapatkan hasil nilai C.R kepuasan inovasi pada 
kepuasan kinerja adalah sebesar 8,494 dengan tingkat signifikansi $\mathrm{p}<0,05$, maka hipotesis 5 didukung. Disimpulkan bahwa kepuasan inovasi berpengaruh positif pada kepuasan kinerja. Semakin tinggi kepuasan inovasi yang dimiliki perajin batik maka kepuasan kinerja perajin batik tersebut juga akan semakin tinggi. Hasil penelitian ini mendukung penelitian yang dilakukan oleh Cruz et al. (2009).

\section{Perilaku Berwirausaha Berpengaruh Positif pada Kepuasan Kinerja}

Berdasarkan hasil perhitungan pada Tabel 3 didapatkan hasil nilai C.R perilaku berwirausaha pada kepuasan kinerja adalah sebesar 1,208 dengan tingkat signifikansi p>0,05, maka hipotesis 6 tidak didukung. Disimpulkan bahwa perilaku berwirausaha tidak berpengaruh pada kepuasan kinerja. Hasil penelitian ini mendukung penelitian yang dilakukan oleh Cruz et al. (2009).

Secara keseluruhan dapat disimpulkan bahwa: a) Program pendidikan kewirausahaan (EEP) berpengaruh positif pada sikap kewirausahaan, norma subyektif, persepsi kontrol perilaku serta kepuasan inovasi. b) Sikap kewirausahaan, norma subyektif dan persepsi kontrol perilaku berpengaruh positif pada niat untuk berwirausaha. c) Niat untuk berwirausaha tidak berpengaruh pada perilaku berwirausaha. d) Kepuasan inovasi berpengaruh positif pada kepuasan kinerja. e) Perilaku berwirausaha tidak berpengaruh pada kepuasan kinerja.

Studi ini disarankan dapat memberikan pemahaman pada praktisi terhadap upayaupaya untuk meningkatkan kepuasan kinerja. Hal ini dapat dilakukan dengan cara meningkatkan inovasi pada produk atau jasa yang dilakukan sehingga dapat meningkatkan penjualan.

\section{PENUTUP}

Keterbatasan dari studi ini adalah obyek amatan pada studi ini difokuskan pada perajin batik di wilayah Kota Surakarta, Kabupaten Sragen, dan Kabupaten Karanganyar, sehingga berdampak pada generalisasi studi yang bersifat terbatas. Hal ini memberikan peluang bagi studi lanjutan untuk mengembangkan model pada konteks yang lebih luas. Namun demikian, diperlukan kehati-hatian dalam mencermati karakteristik yang melekat pada obyek amatan studi.

Penelitian selanjutnya sebaiknya meneliti pada obyek dan setting yang berbeda dan juga dapat menambahkan variabel variabel lain yang belum ada dalam penelitian ini sehingga konsep yang dimodelkan dapat ditingkatkan generalisasinya serta dapat menyempurnakan pemahaman pada faktor faktor yang mempengaruhi kepuasan kinerja.

\section{DAFTAR PUSTAKA}

Ajzen, I. 1991. The theory of planned behavior. Organizational Behavior and Human Decision Processes. 50 (2). 179-211.

Cooper, AC., JF. Gimeno-Gascon and C. Woo. 1994. Initial human and finansial capital as predictors of new venture performance. Journal of Business. 9. 371-95.

Cruz, NM., AIL. Escudero and FS. Leitao. 2009. The effect of entrepreneurship education programmes on satisfaction with innovation behaviour and performance. Journal of European Industrial Training. 33 (3). 198-214.

Fayolle, A., B. Gailly and NL. Clerc. 2006. Assessing the impact of entrepreneurship education programmes: a new methodology. Journal of European Industrial Training. 30 (9). 701-720.

Ferdinand, A. 2006. Metode Penelitian Manajemen: Pedoman Penelitianb untuk Penulisan Skripsi, Tesis dan Disertasi Ilmu Manajemen. Badan Penerbit Universitas Diponegoro, Semarang.

Guido, G., A. Marcati and AM. Peluso. 2011. Nature and antecedents of a marketing approach according to Italian SME entrepreneurs, A structural equation modeling approach. International Journal of Entrepreneurial Behaviour \& Research. 17 (4). 342-360.

Kennedy, J. and J. Drennan. 2001. A review of the impact of education and prior experiance on new venture performance. The International Journal of 
Entrepreneurship and Innovation. 3 (3). $153-69$.

Kolvereid, L. 1996. Prediction of Employment status choice intentions. Entrepreneurship Theory \& Practce. 21 (1). 47-57.

Linan, F and YW. Chen. 2009. Development and Cross-Cultural Application of a Specific Instrument to Measure Entrepreneurial Intentions. Entrepreneurship Theory and Practice.

Riani, Irianto dan Widodo. 2011. Analisis Faktor Penentu Niat Berwirausaha Mahasiswa Universitas Sebelas Maret.
LPPM Universitas Sebelas Maret Surakarta.

Schwarz, EJ., MA. Wdowiak, DA. Almer-Jarz, and RJ. Breitenecker. 2009. The effects on attitudes and perceived envionment conditions on students' entrepreneurial intent An Austrian perspective. Education + Training. 51 (4).272-291.

Tkachev, A. and L. Kolvereid. 1999. Selfemployment intentions among Russian students. Entrepreneurship and Regional Development. 11 (3). 269-80. 